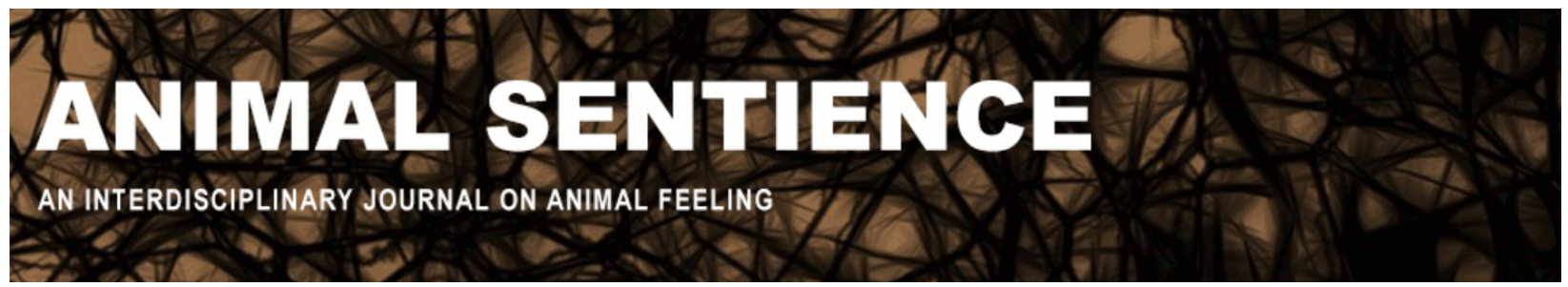

Rollin, Bernard E. (2016) Science and sensibility. Animal Sentience 7(7)

DOI: $10.51291 / 2377-7478.1090$

Date of submission: 2016-02-18

Date of acceptance: 2016-02-24

(c) (i)

This article has appeared in the journal Animal

Sentience, a peer-reviewed journal on animal

cognition and feeling. It has been made open access,

free for all, by WellBeing International and deposited

in the WBI Studies Repository. For more information,

please contact

wbisr-info@wellbeingintl.org.

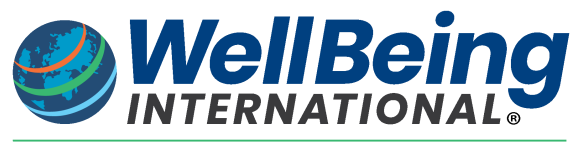

SOLUTIONS FOR PEOPLE, ANIMALS AND ENVIRONMENT 


\title{
Science and sensibility
}

Commentary on $\mathrm{Ng}$ on Animal Suffering

\author{
Bernard Rollin \\ Department of Philosophy \\ Colorado State University
}

\begin{abstract}
The sentience and suffering of animals is obvious to common sense, even if science and industry claim to be agnostic. Economic incentives to reduce the suffering of animals are welcome, but it is not clear whether animals can turn to science for help.
\end{abstract}

Bernard Rollin bernard.rollin@colostate.edu is Distinguished Professor of Philosophy, Animal Sciences and Biomedical Sciences, at Colorado State University. One of the leading scholars in animal rights and animal consciousness, he has lectured worldwide.

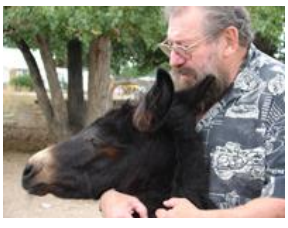
http://philosophy.colostate.edu/people/brollin/

I find myself largely in sympathy with $\mathrm{Ng}^{\prime} \mathrm{s}$ (2016) approach, and particularly appreciate his rather unique attempt to ground the justification for advances in animal welfare in the perspective of economics. Economic considerations are usually invoked by defenders of the status quo, not by its critics. $\mathrm{Ng}^{\prime}$ s analysis creates some new strategies for defending animal welfare against crass appeal to the cheapness of food. In the same vein, those of us who served on the Pew Commission on Industrial Farm Animal Production (2008) came to realize that what is "inexpensive" at the grocery cash register is not necessarily really "cheap," given the significant costs that are "externalized" and are thus invisible to the consumer: (Report of the Pew Commission on Industrial Farm Animal Production: Putting Meat on the Table):

These costs include damage to roads and bridges leading to and from industrialized animal production systems, which are ultimately passed back to consumers as taxpayers.

California health officials informed Pew Commission members that every man, woman and child In the Central Valley locus of large industrial dairies spends approximately $\$ 1500$ more on health care per annum than they would if the dairies were not there.

There are significant costs to the environment, particularly air and water quality, attendant upon the enormous amount of animal waste that must be disposed of. (One security guard at a remote southwestern pig farm proudly informed me that the facility produces "more shit than the city of Los Angeles.") 
There are also major costs to the ultimate sustainability of animal agriculture. If cheap oil were to suddenly vanish, the food supply would be dealt a crippling blow.

Laudable as I found Ng's defense of animal welfare, I do have disagreements with some of his philosophical presuppositions. When I first approached it, I was profoundly excited by the author's announced commitment to common sense, as reflected in his target article's title. This is particularly important to me because of the extensive work I have tried to do to explain the dichotomy between ordinary common sense, and what I have called "scientific ideology" or the "common sense of science." The latter is based in, among other things, an extreme positivistic commitment to denying the reality of qualitative distinctions; to viewing physico-chemistry as the most valid form of explanation; to denying the relevance of ethics to science and proclaiming that science is "value-free," and to denying both the reality and the knowability of mental states in humans and animals (Rollin 2006).

Ordinary common sense, on the other hand, takes the knowability of mind in humans and animals as axiomatic, as well as the relevance of ethics to science. $\mathrm{Ng}$ mentions correctly that it was not until 2012 that the Cambridge consensus conference officially acknowledged thought and feelings in animals (Low et al. 2012). When the research community failed to treat the problem of pain in animals used for research seriously, society legally mandated such control. When the research community failed to articulate and address ethical issues attendant upon the development of biotechnology, the resultant void was filled with bad ethics, such as the claim that genetic engineering "desacralizes nature" or that cloning "violates God's will." In neglecting ethics, science undermines its credibility with the general public.

To develop social policy for controlling animal pain and suffering and for mandating welfaresensitive rules for animal use, we do not need to wait for science to catch up with common sense. Though psychology is now considered to be a science, it has often been remarked that we learn far more about human psychology from the great novelists than we do from psychologists. And even though the cat was one of the most commonly studied animals in the $20^{\text {th }}$ century, that study taught us virtually nothing about normal cat behavior.

Indeed, not only is science replete with value judgments, changes in scientific paradigms can also occur because of changes in values. It is traditionally assumed that scientific ideas are supplanted by other scientific ideas when either new evidence refutes the old theory or the old theory is shown to be logically incoherent. This is not borne out by the history of science. When, for example, the venerable Aristotelian paradigm of a world of qualitative differences was supplanted by the new worldview of Newton and Galileo, it was not because the old paradigm was empirically refuted or shown to be logically flawed - it was more disapproved ${ }^{1}$ than disproved.

\footnotetext{
${ }^{1}$ Obviously, no qualitative empirical data would disprove a qualitative world view based on experience. Rather, thinkers like Descartes argued that qualitative experience is flawed because true sense experiences are qualitatively identical to false ones, otherwise we could not mistake one for another. It was also believed that God was a mathematician, reducing multiplicity to unity. This clearly represents a valuational change.
} 
In The Unheeded Cry: Animal Consciousness, Animal Pain, and Science (Rollin 1989) I tried to show how the prior scientific belief in the reality and knowability of animal mind and consciousness, firmly held by Charles Darwin, was not refuted, but rather supplanted by behavioristic ideology that tantalized with the promise of fixing social ills by way of behavioral engineering.

$\mathrm{Ng}$ is certainly right that the suffering of animals in high confinement agriculture should be a high priority for those of us concerned with reducing their suffering. Animals produced for food, after all, number in the billions annually. But I am skeptical of $\mathrm{Ng}^{\prime}$ s belief in animal research as a key method for remedying that same suffering. Many animal studies fail to to control for pain, stress and distress, as evidenced by Gärtner et al. (1980). The value of research on chimpanzees has been acknowledged to be limited (Knight, 2011). There have been questions about the replicability of animal research (Van de Staay 2009). This all seems to call for skepticism rather than blind faith in animal research. One need not be Konrad Lorenz, for example, to recognize that since pigs have legs, bones, and muscles that require space to meet the demands of their physiology, the widely used gestation crates for sows are an inhumane violation of their basic needs and should be replaced.

Family squabbles aside, I would like to express my thanks to Prof. $\mathrm{Ng}$ for opening a new doorway into the study and actualization of animal welfare.

\section{References}

Gärtner, D., Büttner, D., Döhler, K., Friedel, R., Lindena, J., \& Trautschold, I. (1980). Stress Response of Rats to Handling and Experimental Procedures. Laboratory Animals 14(1980), 267-274

Knight, A. (2011). The Costs and Benefits of Animal Experiments. London: Palgrave-Macmillan

Low, P., Panksepp, J., Reiss, D., Edelman, D., \& Van Swinderen, B. (2012). The Cambridge declaration on consciousness. Francis Crick Memorial Conference on Consciousness in Human and non-Human Animals, Churchill College, University of Cambridge, July 7, 2012

$\mathrm{Ng}$, Y-K. (2016). How welfare biology and commonsense may help to reduce animal suffering. Animal Sentience 2016.007

Pew Commission on Industrial Farm Animal Production (2008). Putting Meat on the Table: Report of the Pew Commission on Industrial Farm Animal Production

Rollin, B. (1989). The Unheeded Cry: Animal Consciousness, Animal Pain, and Science. Oxford University Press

Rollin, B. (2006). Science and Ethics. Cambridge: Cambridge University Press

Van der Staay, F. J., Arndt, S. S., \& Nordquist, R. E. (2009). Evaluation of animal models of neurobehavioral disorders. Behavioral and Brain Functions 5(1), 1 